\title{
Construction and validation of a systematization instrument for nursing in intensive care
}

\author{
Construção e validação de instrumento de sistematização da assistência de enfermagem em \\ terapia intensiva
}

\section{Construcción y validación de instrumento de sistematización de la atención de enfermería en cuidados intensivos}

Daniela Silva de Araújo ${ }^{1}$, Andreza Freire França ${ }^{1}$, João Kelvin da Silva Mendonça ${ }^{1}$, Ana Rita de Cássia Bettencourt ${ }^{2}$, Thatiana Lameira Maciel Amaral ${ }^{1}$, Patricia Rezende do Prado ${ }^{1}$

Objective: construction and validation of a systematization instrument for Nursing Care, characterizing the profile of patients of an intensive care unit in the north of Brazil. Methods: it was a descriptive methodological study that followed a nursing process model in five phases. Results: it was suggested that the instrument be constructed in two formats; one for admission and another for daily assessment. Some items were removed from the instrument according to content validation content by the nurses. Of the 45 patients evaluated, $60.0 \%$ were men, $44.0 \%$ were married, $40.0 \%$ had low education levels, chronic renal failure and cancer. The main nursing diagnoses were risk for infection (100.0\%) and impaired physical mobility (97.8\%). The main nursing interventions were: handwashing, changing intravenous access, performing aseptic techniques and moving patients every 2 hours. Conclusion: construction and content validation were carried out successfully, promoting instruments capable of providing quality nursing care for patients in intensive care.

Descriptors: Nursing Care; Intensive Care Units; Validation Studies.

Objetivo: construir e validar um instrumento de Sistematização da Assistência de Enfermagem e caracterizar o perfil dos pacientes de uma unidade de terapia intensiva do norte do Brasil. Métodos: trabalho metodológico descritivo, seguiu o modelo do processo de enfermagem em cinco fases. Resultados: foi sugerido que o instrumento fosse construído em dois impressos, um de admissão e outro de avaliação diária. Alguns itens do instrumento foram retirados conforme a validação do conteúdo pelas enfermeiras. Dos 45 pacientes avaliados, $60,0 \%$ eram homens, $44,0 \%$ casados, $40,0 \%$ com baixa escolaridade, insuficiência renal crônica e carcinoma. Os principais diagnósticos de enfermagem foram risco para infecção $(100,0 \%)$ e mobilidade física prejudicada $(97,8 \%)$. As principais intervenções de enfermagem foram: lavagem das mãos, trocar acessos endovenosos, realizar técnicas assepticamente e movimentar o paciente a cada 2 horas. Conclusão: a construção e validação de conteúdo foram realizadas com êxito, subsidiando instrumentos capazes de proporcionar aos pacientes uma assistência de enfermagem de qualidade.

Descritores: Cuidados de Enfermagem; Unidades de Terapia Intensiva; Estudos de Validação.

Objetivo: construir y validar un instrumento de Sistematización de la Atención de Enfermería y caracterizar el perfil de pacientes de una unidad de cuidados intensivos del norte del Brasil. Métodos: trabajo metodológico descriptivo, siguiéndose el modelo del proceso de enfermería en cinco fases. Resultados: sugerencia del instrumento construido en dos formas, una de entrada y otra evaluación diaria. Algunos artículos se retiraron del instrumento como validación de contenidos por las enfermeras. De los 45 pacientes evaluados, 60,0\% eran hombres, $44,0 \%$ casados, $40,0 \%$ con baja escolaridad, insuficiencia renal crónica y cáncer. Principales diagnósticos de enfermería: riesgo de infección $(100,0 \%)$ y movilidad física alterada (97,8\%). Principales intervenciones de enfermería: lavado de manos, cambio de acceso intravenoso, realizar técnicas asépticas y mover al paciente cada 2 horas. Conclusión: construcción y validación de contenido se llevaron a cabo con éxito, subsidiándose instrumentos capaces de proporcionar a los pacientes atención de enfermería de calidad.

Descriptores: Atención de Enfermería; Unidades de Cuidados Intensivos; Estudios de Validación.

\footnotetext{
${ }^{1}$ Universidade Federal do Acre. Rio Branco, AC, Brazil.

${ }^{2}$ Universidade Federal de São Paulo. São Paulo, SP, Brazil.

Corresponding author: Patricia Rezende do Prado

Universidade Federal do Acre, BR 364, Km 4, Caixa postal 500, Distrito Industrial, CEP: 69.915-900. Rio Branco, AC, Brazil. E-mail: patyrezendeprado@gmail.com
} 


\section{Introduction}

Nursing care for patients in the Intensive Care Unit is specialized and complex, requiring advanced technological equipment, highly qualified human resources and scientific knowledge $\mathrm{e}^{(1)}$.

In this sense, the implementation of the nursing process in this sector constitutes an important instrument for improving the quality and safety of nursing care, both for patients and for professionals, as it aims to organize nursing care through a systematic individualized data collection instrument ${ }^{(1-3)}$.

The Nursing Process is a method which organizes nursing care, composed of five interdependent and sequenced phases. The first phase consists of nursing history, which aims at collecting patient data through anamnesis and physical examinations, which will guide the identification of potential health-related issues; the next phase is nursing diagnosis, based on data collected in the previous phase and identifying care needs to be provided. In the third phase called nursing planning, the expected outcomes based on nursing diagnoses are tracked along with the nursing interventions to be implemented. In the fourth phase (the implementation phase), the nursing interventions established in the third phase are executed. Finally, in the last phase called nursing evaluation, the results achieved in the implementation phase are analyzed in order to determine whether the expected outcomes have been achieved. It is noteworthy that the entire study should be conducted based on solid scientific knowledge about each abovementioned phase ${ }^{(2)}$.

The Systematization of Nursing Care aims to reduce possible complications during the provision of care in order to minimize the time required for patient recovery. Its execution is regulated by Resolution No. $358 / 2009$, issued by the Federal Board of Nursing, which specifies that systematization is exclusively incumbent to nurses, leaving them the task to implement, plan, organize, execute and evaluate the entire process, by using the method of scientific work for its development ${ }^{(1)}$.
Despite the theoretical consistency and the practical importance they have, the fact is that systematization of nursing care and nursing process are not satisfactorily used in health services ${ }^{(2-3)}$. Some studies cite that a significant number of nursing professionals ignore or know little about systematization $^{(3-6)}$. Consequently, what happens is poor development of nursing care systematization, compromising the quality of nursing care provided to the patient and the autonomy of the nursing professional.

Given the importance of nursing care systematization, especially for systematic and individualized patient care, its implementation in the various health sectors is required. A practical and efficient way to make this work method possible is through the creation of data collection instruments developed in accordance with the principles established by the nursing process. The creation of such instruments facilitates the collection and evaluation of data, and also provides a significant improvement in the quality of care $^{(1)}$.

The implementation of systematization instruments of nursing care in intensive care units has been performed by some researchers in various parts of Brazil, which have produced positive results in the nursing care provided to patients hospitalized in this sector $^{(3-6)}$.

The objective of this study was to construct and validate a systematization instrument of nursing care characterizing patients hospitalized in the (intensive care) unit during the study period.

\section{Method}

This is a descriptive methodological study of construction and content validation of a systematization nursing care instrument and characterization of patients hospitalized in an intensive care unit in the north of Brazil.

The intensive care unit has ten beds, and nine of them are active. According to information from the 
nursing management of this unit, the most common diseases are: chronic renal failure, sepsis, nosocomial pneumonia, pancreatitis, congestive heart failure, and stroke, among others. The average number of hospitalizations during the period of December 2012 to June 2013 was 33 admissions per month.

The initiative of this study arose from the need to assist the training field of the students of the Federal University of Acre for the construction of a systematized nursing data collection instrument. Thus, the construction of the instrument and validation of the nursing care systematization was carried out through the following phases: 1) Meetings with nursing management from the Hospital, the nurses responsible for the intensive care unit and the researchers from the Bachelor of Nursing course at the Federal University of Acre to assess the need and the team's interest in joining the project's objective. 2) A literature review for further construction of the instrument; the search for articles was conducted through the keywords: nursing diagnosis, intensive care, nursing care, systematization of nursing care and validation through the Pubmed and Virtual Health Library databases in the period from 2000 to 2013. It is noteworthy that the nursing instrument used by this unit was also used.

The selected theoretical framework focused on collecting data and relevant information about the physical examination of the critical patient for the construction of the first phase of the nursing process (Nursing History), identifying the most frequent nursing diagnoses in intensive care, nursing care planning and prescription of the care to patient.

The instrument followed the model of the Nursing Process according to the reference of AlfaroLefevre, in five steps: history, diagnosis, planning, implementing and evaluating. This model was chosen for being practical, systematic and familiar for the intensive care unit team ${ }^{(2)}$.

Content validation of the instrument was performed after its construction by the researchers. The validation was performed by nurses and teachers, experts in the area.

The nurse in charge and the general nursing management were contacted to be shown the instrument and to schedule lectures for nurse training on this topic and on the instrument to guide the instrument content validation process.

Initially, a three-hour theoretical class was held for the evaluators in the unit. At this time they were shown how the instrument was designed and they were asked about its validation. In total, four specialist intensive care unit nurses with over ten years of practical experience and two assistant professors evaluated the Nursing Care Systematization instrument. Two more assessments in the unit followed this initial assessment. After agreement of the instrument content between evaluators, a pilot project was simultaneously conducted with two nurses in the instrument application for one hundred and twenty days.

This project was approved by the Ethics Committee of the Federal University of Acre by Protocol 516.912/13.

\section{Results}

\section{Construction of the data collection instrument, Pre-test and content validation - Characterization of patients}

Initially, extensive research was conducted prior to construction of the instrument in relation to the execution of physical examinations on critical patients and on the main diagnoses and nursing interventions in the intensive care unit. With the entire theoretical framework established, the Nursing Care Systematization instrument was elaborated onto a single sheet, being divided into four segments: patient identification, history and physical examination, diagnostic and nursing interventions.

After the preparation of the data collection instrument, a meeting was held with the nurses of the Intensive Care Unit and expert teachers in the area for 
the evaluation of the presented items.

The application of the Nursing Care Systematization instrument in the Intensive Care Unit was conducted for one hundred and twenty days, resulting in the completion of forty-five systematic print outs for admission and sixty print outs for nursing evolution. It should be noted that forms were filled out simultaneously by a nurse from the sector and another by the study researcher.

It was suggested that the instrument should be divided into two print outs: a patient's admission, with identification, history, physical examination, diagnosis and nursing prescription; and another of daily evolution, in which the segment identification was removed.

In the patient identification segment, the items included were date of admission and date of birth, patient name, room, time of entry, registration number, telephone, age, gender, nationality, skin color, marital status, occupation and education level. In history and physical examination, the data collection points included were: medical diagnosis, history of current health problem, comorbidities, allergies, smoking and drinking. The elaboration of the physical examination segment followed the criteria of physical examination by systems: neurological assessment, respiratory, cardiovascular, gastrointestinal, urinary and integumentary systems evaluation.

It should be noted that the vast majority of the questions were prepared in the form of a check list, in order to provide nursing professionals with greater objectivity and speed for filling in the proposed data.

Likewise, it was suggested that the field date of birth in the admission instrument be replaced by current date and also the item anthropometric measures was taken out, because according to the nurses of the sector, it is carried on the back of the medical prescription, thereby it was necessary to be in the proposed instrument.

In the patient identification segment of the patient's printed admission form, the items of time of admission and origin of the patient were proposed to be added. In the daily evolution printout, items on changes in evolution, current date and time, a space for the item of presence of drains, presence of wound and use of sedation were added.

On that occasion, the removal of the items comorbidities, allergies, acceptance of the diet, chewing difficulty, swallowing difficulty, sleep and rest were also suggested. The withdrawal of the last four mentioned items is justified according to the participating nurses because the majority of patients are using sedatives and enteral tubes, which make it impossible to obtain such data. Regarding the removal of comorbidities and allergies items, it was more convenient to keep such information in the data collection instrument, as these data provide important information on the nursing history of every patient.

Some nursing interventions were modified in accordance to the routines of the sector, such as checking vital signs to checking vital signs every 2 hours; conducting fluid balance and communicating change to conducting fluid balance every 6 hours and communicating change; administering heated liquid to administering heated or cooled liquid according to medical prescription; and monitoring enteral nutrition drip to monitoring enteral nutrition drip by infusion pump. Other performed and removed (items) from nursing interventions were supplying high-fiber foods, increasing water intake and weighing patients at appropriate intervals.

The pilot project resulted in 45 completed printed admissions, allowing for the characterization of the patients in the Intensive Care Unit. The average age of the patients was 51.3 years, with standard deviation of 21.6 years, $27(60.0 \%)$ were male, 20 (44.4\%) were married, and 18 (40.0\%) had completed elementary school. The most frequent medical diagnoses were: chronic renal failure and carcinoma, both with a frequency of $20.0 \%$ each (Table 1 ).

Regarding vital signs, the average temperature was $35.9^{\circ} \mathrm{C}$, heart rate of $93.2 \mathrm{bpm}$, respiratory rate of $17.2 \mathrm{mrm}$, median systolic blood pressure of 102.5 mmHg (millimeters of mercury) and diastolic blood 
pressure had an average of $71.8 \mathrm{mmHg}$ (Table 1 ).

The main changes found in the level of consciousness were 15 (33.3\%) comatose patients and 10 $(22.2 \%)$ lethargic patients. In relation to breathing, 19 (42.2\%) were using mechanical ventilation (Table 1).

Table 1 - Characteristics of patients admitted to the Intensive Care Unit

\begin{tabular}{|c|c|}
\hline Variables & n (\%) \\
\hline Age (years) (average \pm standard deviation) & $51.3 \pm 21.6$ \\
\hline \multicolumn{2}{|l|}{ Gender } \\
\hline Male & $27(60.0)$ \\
\hline Female & $18(40.0)$ \\
\hline \multicolumn{2}{|l|}{ Marital status* } \\
\hline Married & $20(44.4)$ \\
\hline Single & $6(13.3)$ \\
\hline Separated/divorced & $2(4.4)$ \\
\hline Widower & $5(11.1)$ \\
\hline \multicolumn{2}{|l|}{ Education level* } \\
\hline Completed elementary school & $18(40.0)$ \\
\hline High school & $8(17.8)$ \\
\hline Higher education & $2(4.4)$ \\
\hline \multicolumn{2}{|l|}{ Medical Diagnostics* } \\
\hline Chronic kidney failure & $9(20.0)$ \\
\hline Carcinoma & $9(20.0)$ \\
\hline Aneurysm & $3(6.7)$ \\
\hline Arthrodesis & $3(6.7)$ \\
\hline Chronic obstructive pulmonary disease & $3(6.7)$ \\
\hline Congestive heart failure & $3(6.7)$ \\
\hline Bowel obstruction & $2(4.4)$ \\
\hline \multicolumn{2}{|l|}{ Vital signs } \\
\hline Temperature (average \pm standard deviation) & $35.9 \pm 1.1$ \\
\hline Heart rate (average \pm standard deviation) & $93.2 \pm 22.1$ \\
\hline Respiratory rate (average \pm standard deviation) & $17.2 \pm 6.1$ \\
\hline Systolic blood pressure(average \pm standard deviation) & $120.5 \pm 31.2$ \\
\hline Diastolic blood pressure(average \pm standard deviation) & $71.8 \pm 21.6$ \\
\hline \multicolumn{2}{|l|}{ Level of consciousness } \\
\hline Lucid & $13(28.9)$ \\
\hline Conscious & $5(11.2)$ \\
\hline Lethargic & $10(22.2)$ \\
\hline Disoriented & $2(4.4)$ \\
\hline Comatose & $15(33.3)$ \\
\hline \multicolumn{2}{|l|}{ Breathing } \\
\hline Spontaneous & $26(57.8)$ \\
\hline Mechanical ventilation & $19(42.2)$ \\
\hline Total & $45(100.0)$ \\
\hline
\end{tabular}

The main nursing diagnoses presented in patients were: risk for infection (100.0\%), impaired physical mobility (97.8\%), impaired skin integrity risk (93.3\%), impaired skin integrity (77.8\%), impaired gas exchange (68.9\%) and inefficient breathing pattern $(64.4 \%)$, with there being the presence of more than one diagnosis for each patient (Table 2).

Table 2 - Nursing diagnoses of patients in the (intensive) care unit

\begin{tabular}{lcc}
\hline Nursing diagnoses & $\mathbf{n}(\%)$ & IC95\% \\
\hline Risk for infection & $45(100.0)$ & - \\
Impaired physical mobility & $44(97.8)$ & $79.0-99.0$ \\
Impaired skin integrity risk & $42(93.3)$ & $73.8-95.2$ \\
Impaired skin integrity & $35(77.8)$ & $57.3-82.7$ \\
Impaired gas exchange & $31(68.9)$ & $48.5-75.5$ \\
Ineffective breathing pattern & $29(64.4)$ & $44.3-71.7$ \\
Risk of aspiration & $29(64.4)$ & $44.3-71.7$ \\
Ineffective spontaneous ventilation & $29(64.4)$ & $44.3-71.7$ \\
Imbalanced nutrition: less than body & $23(51.1)$ & $32.2-59.8$ \\
requirements & $18(40.0)$ & $22.7-49.3$ \\
Ineffective airway clearance & $16(35.6)$ & $19.1-44.9$ \\
Hypothermia & $15(33.3)$ & $17.3-42.7$ \\
Ineffective peripheral tissue perfusion & $15(33.3)$ & $17.3-42.7$ \\
Deficient volume of liquids & $14(31.1)$ & $15.6-40.4$ \\
Acute confusion & $13(28.9)$ & $13.8-38.2$ \\
Decreased cardiac output & $11(24.4)$ & $10.5-33.5$ \\
Pain & $9(20.0)$ & $7.4-28.6$ \\
Excessive volume of liquid & $7(15.6)$ & $4.4-23.6$ \\
Risk of shock & $6(13.3)$ & $3.0-21.0$ \\
Hyperthermia & $4(8.9)$ & - \\
Constipation & $1(2.2)$ & - \\
Diarrhea & & \\
\hline & & \\
& &
\end{tabular}

Nursing interventions showed that the item handwashing was present for all 45 patients (100.0\%), as well as changing central and peripheral intravenous access along with dressings according to protocol, checking vital signs every 02 hours (97.8\%), daily examining of patient's skin (95.5\%) and electrolyte control (93.3\%) (Table 3). 
Table 3 - Nursing interventions of patients admitted to Intensive Care Unit

\begin{tabular}{|c|c|c|}
\hline Interventions & n (\%) & IC95\% \\
\hline Washing hands before and after each patient care & $45(100.0)$ & - \\
\hline Changing central and peripheral intravenous access and dressings according to protocol & $45(100.0)$ & - \\
\hline Performing fluid balance every 6 hours and communicating change & $45(100.0)$ & - \\
\hline Using aseptic technique during procedures & $44(97.8)$ & $79.0-99.0$ \\
\hline Monitoring vital signs every 2 hours & $44(97.8)$ & $79.0-99.0$ \\
\hline Examining the patient's skin daily & $43(95.6)$ & $76.4-95.6$ \\
\hline Monitoring signs of inflammation & $43(95.6)$ & $76.4-95.6$ \\
\hline Doing electrolyte control & $42(93.3)$ & $73.8-95.2$ \\
\hline Performing position change every two hours or as needed & $42(93.3)$ & $73.8-95.2$ \\
\hline Performing passive movements in the patient (nursing and physiotherapy) & $42(93.3)$ & $73.8-95.2$ \\
\hline Inspecting the occurrence of skin lesion & $41(91.1)$ & $71.4-92.6$ \\
\hline Performing thermal curve & $39(86.7)$ & $66.5-89.5$ \\
\hline Performing healing of skin injury & $39(86.7)$ & $66.5-89.5$ \\
\hline Monitoring respiratory status and oxygenation & $38(84.4)$ & $64.2-87.8$ \\
\hline Keep patient in fowler during the administration of food and 30 minutes after the conclusion & $35(77.8)$ & $57.3-82.7$ \\
\hline
\end{tabular}

\section{Discussion}

The construction and validation of the nursing data collection instrument based on the principles of the Nursing Process has been successfully performed by some researchers ${ }^{(2,4,6-7)}$. Similarly, from the results obtained in this study, construction of the instrument aimed at hospitalized patients in this unit was possible, thereby enabling an accurate map of anamnesis and physical examination directed to patients in critical condition and the use of nursing diagnoses and prescriptions.
The content validation, being an essential step for optimal development and adaptation to the proposed sector's reality, sought to follow this process and it was successfully carried out by the nurses and researchers participating in the research. Other researchers have also been able to develop and validate an instrument to collect data for patients in intensive care, as in the present study ${ }^{(8-9)}$.

Most patients in this unit were male, with an average age of 51.3 years, married and with low educational levels. In another intensive care unit, most patients were male (57.1\%), aged 61-80 years 
(42.9\%), illiterate (44.4\%), but most were widowed $(36.5 \%)^{(10)}$.

With regard to nursing diagnoses, the risk of infection was the most prevalent (100.0\%), which confirms other studies and hospital units ${ }^{(11-12)}$, and this diagnosis suggests an increased risk of pathogenic organism invasion ${ }^{(13)}$. This may be explained because hospitalization in these units has increased environmental exposure to pathogens, where a large number of invasive procedures are typically performed $^{(14)}$.

Interventions such as handwashing, performing procedures aseptically, using personal protective equipment, being careful with the injuries, being careful with the incision site, being careful in handling probes, drains and catheters and prevention of cross infection, among others, are some nursing treatments that are valid for reducing the risk of infection in patients ${ }^{(15)}$.

The Nursing Process is considered an appropriate method to explain the essence of nursing, its scientific bases, technologies and humanist assumptions that encourage critical thinking and creativity, and enable solving problems in professional practice. However, a study in Ethiopia hospitals with 14 head nurses from six hospitals and 200 nurses found that the majority, being 180 (90\%), of respondents had little knowledge, but $99.5 \%$ of respondents had a positive attitude towards the Nursing Process. All respondents said that they did not use the Nursing Process in providing care to their patients at the time of the study. The discovery revealed that nurses' knowledge of the Nursing Process is not enough to put it into practice ${ }^{(16)}$.

In this regard, we note that different countries have different knowledge and access in relation to the Nursing Process, its applicability, and its benefits; and research such as this show how constructing a systematization instrument of nursing care can help to use the methodology of the Nursing Process critically, motivating nurses to monitor and evaluate their progress. There is a need to develop mechanisms that increasingly encourages the work of professionals to identify and improve the diseases/injuries found in the intensive care unit, seeking to improve the quality of care provided.

\section{Conclusion}

Despite the collaboration of nurses in validating the content of the instrument, some limitations in developing the study were found with some obstacles in relation to adding important points in the phases of the Nursing Process. For example, introducing related factors and defining characteristics in Nursing Diagnoses and adding spaces to record the times related to Nursing Interventions lead to excessive information in the registry. However, the study stands out for implementing steps of instrument validation aimed for use in the reality of the service and patients.

Another positive point to be noted is that nurses wanted an instrument available for monitoring patients in intensive care, something that would involve them in the validation process. By completing the proposed study, it was possible to provide a systematic and structured nursing data collection instrument.

With the systematic data collection instrument, nursing legitimizes the implementation of systematized nursing care and assistance for effective nursing care and based on scientific methodology.

We hope this study will promote more validation processes for systematization nursing care instruments in other institutions in order to make nursing care more holistic, scientific and directed for critical patients. 


\section{Collaborations}

Araújo DS, França AF and Mendonça JKS contributed to the literature review, analysis and writing of the article. Bettencourt ARC, Amaral TLM and Prado PR contributed to the study design, literature review, analysis and writing of the article. All authors contributed to the critical review and approval of the version to be published.

\section{References}

1. Conselho Federal de Enfermagem (COFEN). Resoluçãonํ. 358, de 27 de 15 de outubro de 2009. Dispõe sobre a Sistematização da Assistência de Enfermagem e a implementação do Processo de Enfermagem em ambientes, públicos ou privados. 2009.

2. Alfaro-Lefévre R. Aplicação do processo de enfermagem: promoção do cuidado colaborativo. 7a ed. Porto Alegre: Artmed; 2010.

3. Silva EGC, Oliveira VC, Neves GBC, Guimarães TMR. Nurses' knowledge about nursing care systematization: from theory to practice. Rev Esc Enferm USP. 2011; 45(6):1380-6.

4. Oliveira APC, Coelho MEAA, Almeida VCF, Lisboa WSQ Macêdo ALS. Sistematização da assistência de enfermagem: implementação em uma Unidade de Terapia Intensiva. Rev Rene. 2012; 13(3):60112.

5. Amante LN, Rossetto AP, Schneider DG. Nursing Care Systematization at the Intensive Care Unit (ICU) based on Wanda Horta's theory. Rev Esc Enferm USP. 2009; 43(1):54-64.

6. Bordinhão RC, Almeida MA. Instrumento de coleta de dados para pacientes críticos fundamentado no modelo das necessidades humanas básicas de Horta. Rev Gaúcha Enferm. 2012; 33(2):125-31.
7. França FCV, Kawaguchi IAL, Silva EP, Abrão GA, Uemura $\mathrm{H}$, Alfonso LM et al. Implementação do diagnóstico de enfermagem na unidade de terapia intensiva e os dificultadores para a enfermagem relato de experiência. Rev Eletr Enf. [periódico na Internet]. 2009 [citado 2013 jan 21]; 9(2):537-46. Disponível em: http://www.fen.ufg.br/revista/ v9/n2/pdf/v9n2a20.pdf

8. Seganfredo DH, Almeida MA. Nursing outcomes content validation according to Nursing Outcomes Classification (NOC) for clinical, surgical and critical patients. Rev Latino-Am Enfermagem. 2011; 19(1):34-41.

9. Costa JB, Marcon SS. Elaboração e avaliação de um instrumento para identificar memórias referentes à Unidade de Terapia Intensiva. J Bras Psiquiatr. 2009; 58(4):223-30.

10. França MJDM, Mangueira SO, Perrelli JGA, Cruz SL, Lopes MVO. Diagnósticos de enfermagem de pacientes com necessidade de locomoção afetada internados em uma unidade hospitalar. Rev Eletr Enf. [periódico na Internet]. 2013 [citado 2013 jan 21]; 15(4):878-85. Disponível em: http://revistas.ufg.br/index.php/fen/article/ view/24221/15658

11. Prado PR, Beccaria LM, Contrin LM. Principais diagnósticos de enfermagem em unidade de terapia intensiva. Cuidarte Enferm. 2009; 3(2):176-83.

12. Souza TM, Carvalho R, Paldino CM. Diagnósticos, prognósticos e intervenções de enfermagem em sala de recuperação pós-anestésica. Rev Sobecc. 2012; 17(4):33-47.

13. North American Nursing Diagnosis Associantion. Diagnósticos de enfermagem da NANDA: definições e classificação 2012-2014. Porto Alegre: Artmed; 2012.

14. Chianca TCM, Lima APS, Salgado PO. Nursing diagnoses identified in inpatients of an adult intensive care unit. Rev Esc Enferm USP. 2012; 46(50):1102-8. 
15. Oliveira MF, Freitas MC. Diagnósticos e intervenções de enfermagem frequentes em mulheres internadas em uma unidade de terapia intensiva. Rev Bras Enferm. 2009; 62(3):343-8.
16. Hagos F, Alemseged F, Balcha F, Berhe S, Aregay A. Application of nursing process and its affecting factors among nurses working in mekelle zone hospitals, Northern Ethiopia. Nurs Res Pract. [Internet] 2014 [cited 2013 Jan 21]; [cerca de 9p]. Available from: http://www.hindawi.com/ journals/nrp/2014/675212/ 